IIUM Journal of Educational Studies, 1:1 (2013) 13-24

Copyright (C) IIUM Press

Exploring Teachers' Perceptions in Managing Interracial Interactions in a Multicultural setting: A Case study of Five Malaysian Secondary Schools in Klang Valley

Azam Othman, Ismail Sheikh Ahmad, Hamidon Abdul Rahman, and Shahrul Fhaizal Shabu

Institute of Education, International Islamic University Malaysia, Kuala Lumpur, Malaysia

azam_othman@iium.edu.my

\begin{abstract}
The multicultural school environment at the Malaysian national schools presents a number of issues and challenges for the in-service teachers. This study investigated the experiences of 16 teachers in five selected national type schools in Klang Valley. Through a series of semi-structured interviews, responses from the teachers provided insights to the multiculturalism school environment in a multiracial society such as Malaysia. The findings of this study revealed that low proficiency of the national language among non-Malay students, inadequate multicultural trainings for teachers, and lack of programmes and initiatives that promote unity in a multicultural environment are among the major hurdles faced by teachers. The implications of the findings and recommendations from the teachers on ways to improve the multicultural environment in schools are also presented.
\end{abstract}

Keywords: multicultural education; multiculturalism in Malaysia; Malaysian schools; teachers' multiracial experience.

\title{
Introduction
}

In its campaigns, the Malaysian Tourism Board proudly proclaims the country as "Truly Asia." Malaysia's population is a mix of the predominant Malays, Chinese, Indians, with smaller minority groups including the indigenous 'Orang Asal', the ethnic groups of East Malaysia, and descendants of immigrants from neighbouring countries as well as afar. As a multicultural society, Malaysians constantly face challenges in sustaining harmonious multiracial relations. These challenges are also faced by teachers in Malaysian national schools. The national schools are government-funded schools and 
IIUM Journal of Educational Studies, 1:1 (2013) 13-24

Copyright (C) IIUM Press

they have the most diverse and largest student population compared to the other types of school in the national education system, that is, Chinese and Tamil or Indian national schools. The Ministry of Education has implemented numerous programmes and policies aimed at strengthening the multiracial unity among the students. Despite these past and on-going efforts, there are evidences suggesting that issues and challenges regarding diversity and multiculturalism in Malaysian schools are still prevalent and in need of proper attention (Abdul Razaq et al, 2011; Mior Khairul Azrin, 2011).

\section{Background of the study}

The Malaysian government has embarked on many programmes and introduced policies in response to the need for multiculturalism in education, including acknowledging the formerly private Chinese and Tamil national schools as part of the National Education System. However, the extent of multiculturalism support in the overall Malaysian education system is still limited. Najeemah (2008) argued that the lack of proper inservice and pre-service multicultural training for teachers is one of the reasons why teachers are inadequately prepared for the challenges of the multicultural environment in schools, where teachers have to constantly deal with students and colleagues of different cultural and religious backgrounds.

Our study explores the experiences of secondary school teachers in selected, culturally diverse secondary national schools in the Klang Valley area. Klang Valley is the nexus of Malaysia's industry and commerce and home to approximately 7.5 million people of various races and ethnicity. Based on our informal discussions with the teachers at the schools, their students are a mix of Malay, Chinese, Indian, second and third generation of Indonesian immigrants, and other minority racial and ethnic groups. The Malays and Chinese are the majority in the urban schools while Indian students are more common in the suburban schools. The Indonesian-descendent students are slightly 
IIUM Journal of Educational Studies, 1:1 (2013) 13-24

Copyright (C) IIUM Press

more difficult to identify because they have assimilated many aspects of the Malay culture including being Muslims, having a Malay-sounding name, and speaking in Bahasa Malaysia instead of Bahasa Indonesia or their own dialect. They are also likely born in Malaysia and possess Malaysian citizenship. Thus, allowing them the access to the national education system. Other minority groups are relatively small in size.

\section{Multiculturalism in schools}

Studies on multiculturalism in schools largely highlight the need for school administrators to be responsive to their students' diverse cultural and religious backgrounds. Banks (2006) outlined five dimensions of multicultural education which include content integration, knowledge construction process, prejudice reduction, equity pedagogy, and an empowering school culture and social structure. They aimed at providing a holistic framework for an education system that champions equality for the different races, ethnicity, and social-economic status groups. The fifth dimension, which is empowering school culture and social structure, describes the school as system with its own set of "values, norms, shared meanings, and an identifiable ethos."

From this particular perspective, it is necessary for schools to properly address the issues and challenges arising from a diverse and multicultural student population. Such instances that have been discussed in previous studies include the struggle of immigrant children adapting to Christianity-majority public school environment (Ng \& Burke, 2004; Gou, 2011), the command of language of instruction and the patterns of discourse among students of different groups (de Abreu \& Elbers, 2005; de Haan et al, 2008); and the treatment of minority students in schools and their perceptions on how the society at large treats their ethnic group affects the minority students' academic performance in school (Ogbu \& Simons, 1998; Antrop-González, 2006). The issues 
IIUM Journal of Educational Studies, 1:1 (2013) 13-24

Copyright (C) IIUM Press

highlighted in these studies may be addressed by teachers if they are given the right guidance, training, and support.

Upholding social justice should be made an important agenda of a multicultural classroom (Muschell \& Roberts, 2011). Students of minority groups often have to shed their cultural and religious identity in order to conform to the norms of the mainstream education system. At the same time, very few efforts had been made to accommodate their cultural and religious practices. Cultural responsiveness in schools, both inside and outside the classrooms, is an important outcome for multicultural classrooms. Besides accommodating the cultural diversity that exists in the school, cultural responsiveness is about ensuring the academic success of every student regardless of their background by assisting them to learn in an unnatural cultural condition (Brown, 2007; Bazron et al, 2005). Positive changes towards improving the level of multiculturalism in schools can be made through incorporating activities that encourages students to learn about each other's cultural and religious background. Engaging in internal self-reflection can also help the teacher to assess their own prejudice towards students' culture and to learn to deconstruct cultural myths and stereotypes (Bae \& Clark, 2005). Early, pre-service exposure to other cultures and religions during their training and practicum can help teachers tremendously in preparing themselves for a culturally diverse classroom (Milner et al, 2003). Teachers may also benefit from a multicultural training that is designed around the multicultural experience itself such as, by inviting teachers of different nationalities to participate in weekly online discussions on their teaching experiences. It acts as a safe and comfortable environment for teachers to discuss, reflect, and compare views on teaching in a multicultural environment, especially, if they have very little experience with cultures other than their own (Lacina \& Sowa, 2005). 
IIUM Journal of Educational Studies, 1:1 (2013) 13-24

Copyright (C) IIUM Press

\section{Multiculturalism in Malaysian schools}

Education has been perceived by the Malaysian government as a way to unite the many ethnic groups in Malaysia. One of the aims of the National Education Policy is "to inculcate and nurture national consciousness through fostering common ideals, values, aspiration and loyalties in order to mould national unity and national identity in a multiracial society" (Najeemah, 2006).

The demand for mother-tongue education has led to the acceptance of vernacular Chinese and Indian schools as part of the national government school system. The Malays, the largest racial group in the country, mostly send their children to national schools while a small number choose both the government and private Islamic religious schools. The overall ratio of Malay and non-Malay students in national schools is staggeringly disproportionate. According to Sin Chew Jit Poh (2005) and Ang \& Che Radiah Mezah (2012), about 7\% non-Malay students attend the national schools all over Malaysia. The different types of school have segregated the Malaysian education system and appear to limit the opportunities for Malaysian students to interact and learn about each other's culture (Montesino, 2011).

According to the Malaysian Ministry of Education Act 1996 (2010), Bahasa Malaysia (BM) or the Malay language is the main medium of instruction for Malaysian national schools. The introduction of the 'Teaching and Learning of Science and Mathematics in English' policy or 'Pengajaran dan Pembelajaran Sains dan Matematik Dalam Bahasa Inggeris ' or PPSMI in 2003 has resulted in a dual language instruction system, where most subjects are taught in the Malay language or BM and Science and Mathematics are in English. Students are expected to be adequately proficient in both languages in order to do well academically. In 2010, the Ministry of Education announced that PPSMI has been reverted to a new policy known as 'To Uphold Bahasa 
IIUM Journal of Educational Studies, 1:1 (2013) 13-24

Copyright (C) IIUM Press

Malaysia and To Strengthen the English Language' or in the Malay language 'Memartabatkan Bahasa Malaysia dan Mempertingkatkan Bahasa Inggeris' or (MBMMBI).

Abdul Razaq et al. (2011) surveyed the perception of Malaysian teachers on diversity and found that the teachers' view of diversity is still moderately low despite the trainings conducted by the Ministry of Education. A more detailed study of Malaysian teachers in the secondary school level revealed the gaps in the multicultural training among the national school teachers (Najeemah, 2008). Multiculturalism is taught in the teacher training programmes either through special courses or as a course. Neither of the approaches mentioned were found sufficient nor satisfactory. The university-trained teachers reflected that trainings only allowed them to learn multiculturalism mostly from the theoretical point of view.

Multiracial interactions among Malaysian students of different ethnicities have always been a concern, despite the abundance of material and references related to cultural diversity in Malaysia's national curriculum (Fakhri, 2012). One of the major steps taken by the Malaysian Ministry of Education was to address this issue by introducing the Vision School project. Vision Schools house national schools together with Chinese and Indian vernacular schools in the same vicinity. The schools share common facilities such as canteen and sports field. The schools maintain their individual autonomy in terms of administration. The outcome of the project has been promising (Malakolunthu, Saedah \& Rengasamy, 2010). A number of teachers mentioned the lack of any official guideline or framework which raised questions about the actual objectives and direction of the Vision Schools. The schools went on with their agendas as separate entities despite the shared compound and aspirations. Despite its 
IIUM Journal of Educational Studies, 1:1 (2013) 13-24

Copyright (C) IIUM Press

noble objectives, the project did not sufficiently address the realities of diversity and multiculturalism in Malaysia (Malakolunthu, 2009).

Another initiative by the Malaysian Ministry of Education is the Student Integration for Unity Plan or ‘Rancangan Integrasi Murid Untuk Perpaduan’ (RIMUP). RIMUP is specifically aimed at fostering and strengthening unity among Malaysian students of national and vernacular schools through joint activities. It was first introduced in 1986 and the plan has undergone changes and revisions over the years in terms of its scope and implementation. The Ministry of Education (2011), one of the most distinctive features of RUMIP is the involvement of the local community. As a measure for promoting national unity, RIMUP holds substantial potential as it brings together the different types of schools as well as the members of the public (Montesino, 2011).

\section{Methodology}

This study employed a qualitative methodology using the phenomenological approach. Phenomenology examines in detail the phenomenon in question by looking at it from the perspective of the people involved, and through processes and interactions that occurred therein. Understanding of the phenomenon is obtained by conducting interviews with the informants, written field notes, and other documents. Phenomenologists do not begin their inquiry assuming they know what they are going to study, but instead seek to discover what the people involved might take for granted (Bogden \& Biklen, 2007). This study focused on the following research questions:

(1) How do the teachers perceive cultural differences in a multicultural school setting?

(2) What kind of experiences teachers go through in a multicultural school setting? 
IIUM Journal of Educational Studies, 1:1 (2013) 13-24

Copyright (C) IIUM Press

(3) How do teachers manage multiracial interactions in in a multicultural school setting?

(4) What are the strategies used to deal with issues related to multiracial relationships?

(5) What are teachers' recommendations in enhancing multiracial relationship in a multicultural environment?

Based on their location and racial diversity of the population, six urban and suburban schools in Selangor, Kuala Lumpur, and the Klang Valley area were selected as the sample. Sixteen teachers from the schools agreed to be interviewed with permission given by their respective headmasters. The teachers are selected based on their years of service and race. Half of the teachers were interviewed as a focused group while and the other half were interviewed one-to-one. The reason for the focus group was to accommodate the teachers' time and the time they are allowed to be at the schools. Each group consisted of about there to four teachers. The interviews were semi-structured in nature and the sessions were recorded digitally using audio recorders and video cameras.

The interviews were then transcribed for the coding process and extraction of themes. Thematic analysis approach was used as the basis for the coding process and for extracting the themes. The reliability of the themes was checked with the help of two senior researchers. After the themes have been agreed upon, they were organized according to the research questions and discussed in further detail in the succeeding sections. 
IIUM Journal of Educational Studies, 1:1 (2013) 13-24

Copyright (C) IIUM Press

\section{Findings}

This study focused on understanding the teachers' experiences in a multicultural school setting. The findings we present here are organised based on an interview protocol that was developed from the research questions.

\section{Perception of cultural differences}

Perceptions about cultural differences held by teachers mainly revolve around two main themes, the cultural differences that exist in the school and the individual socioeconomic status. Most of the teachers reported that they have a good relationship with colleagues of a different racial and religious background, but at the same time they perceived multiracial interactions as a process of compromise. Cultural differences, at different times, had to be accepted, celebrated, ignored, or negotiated. In a multicultural environment of the school, teachers had to constantly manage the differences between the cultures.

The issue of food has been brought up by several teachers, mostly regarding the issue of 'halal' food for the Muslims and vegetarian food for the Hindus. 'Halal' is the Islamic set of guidelines that determine whether a food or drink can be consumed by Muslims. The 'halal' requirement includes the prohibition of pork, alcoholic substances, animals not slaughtered according to the Islamic requirement, and also include conditions for food as such the prohibition of stolen food.

According to the non-Muslim teachers, Muslim teachers were reluctant to eat food that they prepare or serve during gatherings or school organised programmes. Some of the non-Muslim teachers critically questioned, in separate interviews, whether it is fair or not for the Muslims do so. A vegetarian Indian teacher also questioned this perception because entirely plant-based foods are generally 'halal' and Muslims should 
IIUM Journal of Educational Studies, 1:1 (2013) 13-24

Copyright (C) IIUM Press

have no problems consuming them. He compared what he observed at his school with what he experienced growing up,

... When I was young, I'm from Kedah, when I was in primary school I had no problems. Everyone (pay each other) visits, Malays, Indians. I lived in a rubber plantation estate. No problems. Everyone ate (what we served).

Exposure to other cultures and religions, whether directly in real life or through a course or training can have an impact on the teachers' outlook on multiracial interactions. An undergraduate course on understanding of the Malay culture can help a Chinese teacher to deal effectively with her Malay students and to guide non-Malay students to understand their Malay friends and teachers better.

The socio-economic status of the students appears to be another factor that affects the level of multiracial interactions in the schools, especially among the students. Parents play a pivotal part in encouraging children to interact with peers of different cultural and ethnic backgrounds. Students from the middle class and upper middle class families appear to fare better in a multicultural environment as their parents seemed to be more open to other cultural and religious views, passing on the same ideals to their children. In one of the schools in our sample, where the students are mostly from wellsituated families, the teachers talked about Chinese female students wearing traditional Malay-style 'baju kurung' uniform to school and conversing with friends of other races in Bahasa Malaysia (BM).

\section{Experiences teaching in a multicultural school}

Overall, the experience of teaching in a multicultural school among Malay and nonMalay teachers differ in how they cope with cultural norms in their respective schools. In the schools that we visited, Muslim Malays were the largest racial group both in 
IIUM Journal of Educational Studies, 1:1 (2013) 13-24

Copyright (C) IIUM Press

terms of student percentage and number of teachers and administrators. In addition, the cultural norms at these schools are influenced by the Malay cultural and Islamic practices.

As teachers, their most salient recollections of experiences were about dealing with the students. The students' behaviour towards them was highly influenced by the language and cultural similarity that they share with the teachers. In conflicting situations, teachers and students appear to cooperate better with someone who has similar cultural and religious backgrounds. A Malay teacher spoke about her inability to get her Chinese students to properly dry themselves or change their clothes after playing basketball before her class starts.

"I reprimanded them many times. And they don't listen. They unashamedly took off their shirts, still drenched in sweat; they enter the class and sit together in a group. They wore their shirt, and later they took it off, if they felt sticky, then they put it back on, they simply do as they please... If the (Chinese) Assistant Headmaster comes in, immediately on-the-spot you will see their attitude change a hundred per cent. They can change a hundred per cent."

Similarity in language and culture also explained why the membership of certain student clubs and societies are made of a particular racial group. This observation resembles the finding by Najeemah (2006) in her study of secondary national school students in the northern states of Penang and Kedah. The students find it easier to join a club or society that has many students who speak the same language or mother tongue, and sometimes because they feel they are not proficient enough to communicate in the Malay language or Bahasa Malaysia.

Poor command of the BM among the non-Malays affects the teaching and learning process as well. In many schools, this problem is exacerbated through the 
IIUM Journal of Educational Studies, 1:1 (2013) 13-24

Copyright (C) IIUM Press

practice of class streaming. In class streaming, students are clustered in classes based on their academic performance level. The better performing students are often placed together in so-called 'front classes', while the less performing ones are placed in the 'back classes.' A senior Indian teacher explained,

"In term of teaching and learning practices, actually, there are no differences (between the classes). It's just that I see, with the 'back' classes it's difficult to apply the teaching and learning practices, isn't it? With the 'front' classes there's no problem, they can follow (the lessons). Because, the way I see it, the problem here is language. Language is causing the ('back') classes, when they don't understand, they can't follow, (and then) they become bored."

Differences in cultural background can also result in differences in how politeness and moral conduct are viewed. A senior female teacher voiced her concerns about the rambunctious way some Indian students treated one another, which to students was something normal.

"The way they interact is so rowdy. I mean the way they talk, yelling at their friends, the way they play. The Indian students, they slug their friends. At first I was puzzled, why are you rough with your friends? This is how they joke with each other, boy or girl. They were even rough with the girls. I said, eh, she's a girl, you can't do that. That's inappropriate."

Students are expected to show polite and good conducts at school. Some of the conducts include greeting of teachers they meet in or out of their classrooms. The teachers mentioned that non-Malay students were not greeting their teachers as often as the Malay students. To address this behaviour, some of the teachers started by modelling the appropriate behaviours to the students.

"What I did was I greet them. When I we greet them, "Good morning," sometimes they reply, "Morning, teacher." Then the next time we see them, they will say, "Hi, 
IIUM Journal of Educational Studies, 1:1 (2013) 13-24

Copyright (C) IIUM Press

teacher, how are you?" They respond. When they see us greeting them, next time they will greet us. It means we're the one who have to make the initiative."

Some non-Malay students are inadvertently perceived as being disrespectful towards their teachers because they use the pronoun I or in the Malay language, 'aku' instead of 'saya.' For formal conversations, 'saya' is the most acceptable form. It is considered disrespectful and even offensive in the context of the Malay culture, when a person refers to him or herself as ' $a k u$ ' while speaking to an elder or respectable person. 'Aku' is more suitable when a person is talking to peers or someone younger. The teachers had to explain to the students that using ' $a k u$ ' when speaking to a teacher is very inappropriate.

The various aspects of culture including language and expectation of conducts and behaviours become entangled in a multicultural school environment. In such an environment, prejudice, and other forms of cultural challenges are unavoidable, but teachers can deal with them effectively when they recognise their primary causes.

\section{Approaches and strategies in managing the challenges of inter-racial interactions}

The teachers interviewed mainly agreed that managing interracial interactions in a multicultural school environment requires a good understanding of the various cultural and religious practices and values that exist in the schools. Most of the teachers initially said that they all get along well with their colleagues, but after probing, the teachers disclosed that at times cultural and religious matters had soured an otherwise good relationship. One example given was the issue of vegetarian food, which was brought up several times during the interviews. 
IIUM Journal of Educational Studies, 1:1 (2013) 13-24

Copyright (C) IIUM Press

For strict practicing vegetarians, it is unacceptable to have non-vegetarian food served near or cooked using the same utensils as vegetarian food. However, since vegetarian teachers are often the minority group, they often have to keep silent and not complain about it in order to avoid any issues with the rest of the teachers. An Indian teacher complained that he cannot eat at the canteen because beef is cooked and served there. Cows are considered as sacred by the Hindus and vegetarians, especially strict vegetarians, they do not eat any food cooked using cookware that has been used to cook animal meat.

Another Indian teacher seen as being strict about food says that it is something that boils down to the individual. It is also interesting to note how she, being a Hindu, made her arguments using Islamic concepts.

“That one depends on personal opinion... You know they've ready given the respect. Either you want to accept or not. Don't make it an issue. If it feels OK, then accept it. It like (what the Muslim have), the sunat (non-obligatory religious observance) and the wajib (obligatory religious observance), right?"

The views by the two Indian teachers suggest that the multiracial interactions among Malaysians, including between teachers and students, are strongly tied to religion and culture. Forming harmonious multiracial relationship needs to begin with understanding and awareness for each other's religious and cultural background.

In the classrooms, the teachers resorted to equity pedagogy approaches to help the students in their learning. Equity pedagogy involves using the most suitable approaches that can help students of different groups to improve their academic achievement (Banks, 2006). One of the techniques as mentioned earlier was to enlist the help of students who have better command of BM to act as translators. Another technique mentioned was the use of realia or teaching aids. According to a teacher who 
IIUM Journal of Educational Studies, 1:1 (2013) 13-24

Copyright (C) IIUM Press

teaches Commercial Studies to upper secondary students, uses pictures to explain the concepts of the subject to the students in her class has worked very well. The students form their own understanding of the concepts being taught by looking at the pictures and they discuss the concepts amongst themselves, sometimes using their mother tongue. Although this approach seemed to help the students to learn, their performance in the examinations is still poor because they are unable to write answers in BM properly.

At an all-girls school we visited, the teachers took a more proactive approach in promoting good interracial relationships. When they came across something in the syllabus pertaining to the culture of a race, they ask the students to describe cultural analogues that may exist in their own culture. This approach allows students to gain a wider understanding of other cultures by learning about it from one another through honest discussions about multicultural issues. The students also learn to separate cultural facts from cultural misconceptions.

An approach that has worked well, in the teachers' opinion, was to have group activities. The students also seemed to be more engaged during activities held outside the classroom. They teachers instructed students to form groups with students from different races and then, they were instructed to work together to accomplish the goals of the activities. Being outside the classrooms gave the students opportunities to interact in a less formal learning environment while doing something they may enjoy. Some of the activities that have been organised include camping and cooking competitions. Cooking and food-related activities are good ways for students to learn and understand the culture of their friends (Gatenbly et al, 2011). Although critics of such activities believed that they are mostly superficial and simplistic, Richardson (2010) argues 
IIUM Journal of Educational Studies, 1:1 (2013) 13-24

Copyright (C) IIUM Press

otherwise and he states that they can actually help towards "strengthening schoolcommunity partnerships for social transformation.”

\section{Teachers' recommendations}

Towards the end of each interview, the teachers were asked to recommend ways that would enhance multiracial interactions in multicultural school environment. Their recommendations can be grouped into the following three main ideas.

\section{Improving the teaching of BM}

$\mathrm{BM}$, as the language of unity, has long been part of the Malaysian government's effort to spur racial integration among the multiracial Malaysian society (Alis, 2012). The use of a common language can facilitate communications in and outside the classrooms, including the communications between schools, teachers, and students' parents. However, many non-Malay students who have poor command of BM often come from homes where BM is rarely spoken. The school is actually their first experience of actively using BM (Ang \& Che Radiah, 2012). Some of the students previously attended vernacular Chinese or Indian primary schools, where their mother tongue is used widely compared to BM. Improving the teaching of BM is a critical step towards improving multiracial understanding in the multicultural national schools.

\section{Parental involvement}

Parental involvement was not among the most frequently-mentioned responses. However, its significance in improving multiracial understanding in schools should not be overlooked. Parents, just like the teachers, act as role models to their students in fostering multiracial relationships. They can assist the teachers to understand the students' cultural or religious issues by having an open discussions and being actively 
IIUM Journal of Educational Studies, 1:1 (2013) 13-24

Copyright (C) IIUM Press

involved in school programmes. School-organised programmes, especially the ones aimed at improving multiracial understanding, will not achieve their intended objectives if parents do not show enough support. As one teacher pointed out, the first challenge they need to address is creating awareness among parents, as many parents are not properly informed about such programmes in the first place.

\section{Initiatives by teachers and schools}

Teachers can take the lead towards improving multiracial relations. Some schools, such as the all-girls schools, have successfully incorporated multicultural programmes into the school's annual agenda. The programmes include cultural performance on Teachers' Day and school-wide celebration of major festivities. A crucial aspect about these programmes at the school is the involvement of the teachers. Teachers even went on stage to perform alongside the students, modelling the behaviours that promote multiracial understanding.

Another programme that has been implemented is the mentor-mentee programmes. As mentors, teachers can assist their students, the mentees, to overcome prejudices and misconceptions by discussing topics such as challenges that they commonly experienced regardless of their background. Throughout the course of the conversation, teachers can help the students to relate to one another as they learn to see the common threads in sharing experiences.

Schools can foster better multiracial harmony by appreciating teachers who haves shown exemplary behaviours in their multiracial interactions. They are a role model for both their peers and their students. Physical aspects, such as the location of the teachers' room, can affect the quality of the teachers' interactions and relationship. 
IIUM Journal of Educational Studies, 1:1 (2013) 13-24

Copyright (C) IIUM Press

In one school, the teachers' room were located in separated buildings and the teachers there did not know many of their colleagues from the building even after working in the same school for years.

\section{Discussion}

The findings suggest that the teachers continually face issues and challenges of multiculturalism because they are not adequately supported in terms of realising one of the major aspirations of the national education system and that is to build multiracial unity among Malaysians at the school level. Understandably, the Malay-Muslim ideals of culture appear to be dominating the discourse on multiculturalism at the urban Malaysian secondary schools, simply because the Malay-Muslims are the major race and religious group. There has not been much room to accommodate the other coexisting cultures which includes cultures of other Muslims such as the Chinese-Muslims and the Indian-Muslims.

Many Non-Malays, both teachers and students, appear to have a good idea about what is allowed or not allowed in the Malay-Muslim culture. They understand that pork is 'haram' or not permitted is Islam and thus, school canteens should not serve any food that contains pork. As the interviews revealed, the teachers' overall understanding for other cultural and religious practices, such as vegetarianism practices among Hindus, were relatively lower compared to their understanding for Malay-Muslim cultural and religious practices. Such lack of understanding has made some of the teachers feel that their culture or religious beliefs are not properly respected.

The findings of this study raises a number of questions about how far has the national education system succeeded in its aim to unite the different races in Malaysia? The findings presented here, together with the assessments by a few others suggest that 
IIUM Journal of Educational Studies, 1:1 (2013) 13-24

Copyright (C) IIUM Press

more effort is needed in preparing and supporting teachers in dealing with the multicultural issues (Malakolunthu et al, 2010; Ang \& Che Radiah Mezah, 2012; Abdul Razaq et al, 2011; Najeemah, 2006). Najeemah (2008) noted that the existing multicultural training for teachers are still insufficient and does not seem to be thoroughly planned and organized. Besides equipping the teachers with the necessary skills to teach effectively in a multicultural classroom, the scope of training should also be widened to include training that can help them to understand the various cultural and religious practices of their students and colleagues. Similar training should also be offered to school administrators to assist them in the planning programmes and policies that can effectively promote good multiracial relations in their school community.

The teachers also commented that to better understand multiculturalism in schools, it is a collective effort. Every stakeholder including the parents and the local community can play their respective parts in encouraging better multiracial unity. The tolerance for diversity in a multicultural environment requires reinforcement and cooperation from the teachers at the school and parents at home (Onyekwuluje, 2001). Programmes such as RIMUP can be further developed into something that can substantially build the value of multiracial unity among Malaysian from an early age.

One of the most salient issues that has been highlighted in our findings is the issue of BM proficiency especially among the non-Malays. Although it was not discussed in detail in the interviews, the cause of this problem could attributed to the fact that students come from Chinese of Tamil primary school before they enrolled in the national secondary school. In their previous schools, BM is taught as a subject and their mother tongue is the medium of instruction. When the students move from a vernacular primary school to a national secondary school, they had to adjust to the present medium of instruction that is, from their mother tongue to BM. Their 
IIUM Journal of Educational Studies, 1:1 (2013) 13-24

Copyright (C) IIUM Press

proficiency in BM is poorer than their peers of the same racial group who had previously attended a national primary school (Yau, 2011). The recently announced policy of the Ministry of Education on MBMMBI can be seen as a way of overcoming this issue. The policy reaffirms the role and significance of BM as the language for unity and nation-building as well as the role of the English language as the international language of communication. Among the strategies outlined under this policy is to increase 90 minutes of the time allocated for language teaching for both BM and English in the Chinese and Tamil schools that is, from 210 minutes to 300 minutes for BM and from 150 minutes to 240 minutes for English.

\section{Conclusion}

The study unearthed a number of issues and challenges regarding multiculturalism in Malaysian secondary schools as viewed by the teachers. These issues and challenges have to be addressed more comprehensively and strategically if the aspiration for unity and nation-building are to be achieved. Open and honest dialogues among the policymakers, teachers, students, and school administrators who are free from racial, religious, and political sentiment which is greatly needed in order to properly address the underlying issues of multiculturalism in Malaysian schools. It is hope that the younger generation of Malaysians would benefit from an education system that unifies them and educates them towards becoming citizens who respects and appreciates the multiculturalism of the society in which they belong.

The limited scope of this study suggests that the issues and challenges regarding multiculturalism in Malaysian secondary school can be explored further in other contexts. Our objective in this study is mainly on the experience of teachers in national secondary schools and the sample was restricted to only a selected group of urban and 
IIUM Journal of Educational Studies, 1:1 (2013) 13-24

Copyright (C) IIUM Press

suburban national secondary schools within Klang Valley. Future studies on issues and challenges in a multicultural school environment could venture into the possibility of studying the different types of schools in Malaysia and by including the perspectives of other stakeholder such as the school administrators and the local community. Furthermore, a different form of cultural diversity can be found in many parts in Malaysia such as the East Malaysian states of Sabah and Sarawak, which is home to over 40 different ethnic groups.

The main contribution of this study is to present examples and evidence regarding the experiences of multiculturalism in Malaysian schools, particularly among the in-service teachers. Some of the issues presented is recurrent and have not been critically addressed for many reasons, both evident and implied. On a more hopeful note, the issues of multiculturalism in Malaysian schools can actually be an invaluable opportunity for concerned and informed members of the Malaysian society to contribute towards improving the learning and working environment in the Malaysian national schools. 
IIUM Journal of Educational Studies, 1:1 (2013) 13-24

Copyright (C) IIUM Press

\section{References}

Abdul Razaq Ahmad, Norhasni Zainal Abidin, Zalizan Mohd Jelas, \& Anisa Saleha (2011). Teachers' perspectives towards schools diversity in Malaysia. International Journal of Business and Social Science, 2(4), 178-189.

Alis Puteh (2012). "Medium Of Instruction Policy In Malaysia: The Fishman's Model." "European Journal of Business and Social Sciences, 1(1), 11-22.

Ang L. H. \& Che Radiah Mezah (2012). Masalah Penggunaan Bahasa Melayu dalam Kalangan Pelajar Etnik Cina di Malaysia. Sosio Humanika, 5(2), 215-226.

Antrop-González, R. (2006). Towards the School as Sanctuary concept in Multicultural Urban Education: Implications for small High School reform. Curriculum Inquiry, 36(3), 273-301.

Bae, S. J., \& Clark, G. M. (2005). Incorporate diversity awareness in the classroom: what teachers can do. Intervention in School and Clinic, 41(1), 49-50.

Banks, J. A. (2006). Cultural Diversity and Education: Foundations, Curriculum, and Teaching ( $5^{\text {th }}$ ed.). Boston, MA: Pearson Education.

Bazron, B., Osher, D., \& Fleischman, S. (2005). Creating culturally responsive schools. Educational Leadership, 63(1), 83-84.

Brown, M.R. (2007). Educating all students: creating culturally responsive teachers, classrooms, and schools. Intervention in School and Clinic, 43(1), 57-62.

Bogdan, R. C. \& Biklen, S. K. (2007). Qualitative Research for Education (5th ed.). Boston, MA: Pearson Education.

de Abreu, G. \& Elbers, E. (2005). The social mediation of learning in multiethnic schools: introduction. European Journal of Psychology of Education, 20(1), 311.

de Haan, M., Keizer, R., \& Elbers, E. (2010). Ethnicity and student identity in schools: an analysis of official and unofficial talk in multiethnic classrooms. European Journal of Psychology of Education, 25(2), 176-191.

Fakhri R.K. (2012). The Malaysian experience in developing national identity, multicultural tolerance and understanding through teaching curricula: Lessons learned and possible applications in the Jordanian context. International Journal of Humanities and Social Science, 2(1), 270-288.

Gatenby, L. A., Donnelly, J. \& Connell, R. (2011).Cooking Communities: using multicultural after-school cooking clubs to enhance community cohesion. Nutrition Bulletin, 36(1), 108-112. 
IIUM Journal of Educational Studies, 1:1 (2013) 13-24

Copyright (C) IIUM Press

Gou, Y. (2011). Perspectives of immigrants Muslim parents: advocating for religious diversity in Canadian schools. Multicultural Education, 18(2), 55-60.

Lacina, J. G. \& Sowa, P. (2009). Preparing for multicultural schools: teacher candidates dialogue online with teachers from Egypt, Japan, Ghana, and the U.S. Teachers Education Quarterly, 32(1), 61-75.

Malakolunthu, S. (2009). Educational reform and policy dynamics: a case of the Malaysian "Vision School" for racial integration. Educational Research for Policy and Practice, 8(2), 123-134.

Malakolunthu, S., Saedah S., \& Rengasamy, N. C. (2010). Multicultural education as a reform initiative: reconstructing teacher preparation for Malaysian "Vision Schools." The Asia-Pacific Education Researcher, 19(3), 453-464.

Milner. H. R., Flowers, L. A., Moore, E., Moore, J. L., \& Flowers, T. A. (2003 Preservice teachers' awareness of multiculturalism and diversity. The High School Journal, 32(1), 63-70.

Ministry of Education Malaysia (March 26, 2010). To Uphold Bahasa Malaysia and To Strengthen the English Language. Retrieved from http://www.moe.gov.my/ mbmmbi/index.htm

Ministry of Education Malaysia (September 13, 2011). Model Baru RIMUP Akan Diperkenalkan. Ministry of Education Malaysia. Retrieved from http:// buletinkpm.blogspot.com/2011/09/model-baru-rimup-akan-diperkenalkan.html

Mior Khairul Azrin Mior Jamaluddin. (2011). Sistem Pendidikan di Malaysia: dasar, cabaran, dan pelaksanaan ke arah perpaduan nasional. Sosio Humanika, 4(1), 33-48.

Montesino, M. U. (2011). Cross-cultural conflict and affirmative action: inter- and intraethnic dilemmas of Malaysia's heterogeneous workplace. International Journal of Cross Cultural Management, 12(1), 115-132.

Muschell, L.H. \& Roberts, H.M. (2011). Bridging the cultural gap: one teacher education program's response to preparing culturally responsive teachers. Childhood Education, 87(5), 337-340.

Najeemah Mohd Yusof (2006). Patterns of social interaction between different ethnic groups in Malaysian secondary schools. Jurnal Pendidik dan Pendidikan, 21(2006), 149-164.

Najeemah Mohd Yusof (2008). Multicultural education: managing diversity in Malaysian schools. Malaysian Education Deans Council Journal, 2. Retrieved from http://web.usm.my/education/publication/10\%20najeemah\%28149-165\% 29.pdf 
IIUM Journal of Educational Studies, 1:1 (2013) 13-24

Copyright (C) IIUM Press

Ng, E.S.W. \& Burke, R.J. (2004). Cultural values as predictors of attitudes towards equality and diversity: a Canadian experience. Women in Management Review, 19(6), 317-324.

Onyekwuluje, A.B. (2000). Adult role models: needed voices for adolescents, multiculturalism, diversity, and race relations. The Urban Review, 32(1), 6785.

Ogbu, J.U. \& Simons, H.D. (1998). Voluntary and involuntary minorities: A culturalecological theory of school performance with some implications for education. Anthropology and Education Quarterly, 29(2), 155-188.

Richardson, T. A. (2011). At the garden gate: community building through food: revisiting the critique of "Food, Folk and Fun" in multicultural education. The Urban Review, 43(1), 107-123.

Sin Chew Jit Poh. Jun 26, 2005. Kuala Lumpur, Malaysia.

Yao, S.T. (2011). The administrative climate and context of inclusive elementary schools. Asia Pacific Journal of Education, 31(1), 1-18. 